\title{
Implementasi Metode Hybrid Case-Based Reasoning Untuk Mendiagnosa Pengidap Penyakit Post-Traumatic Stress Disorder(PTSD)
}

\author{
Erdina Daniati Simanjuntak, Hery Sunandar, Rivalri Kristianto Hondro \\ Program Studi Teknik Informatika, STMIK Budi Darma, Medan, Indonesia \\ Email: erdinadniati@email.com \\ Submitted 16-03-2020; Accepted 20-04-2020; Published 26-04-2020
}

\begin{abstract}
Abstrak
Post Traumatic Stress Disorder adalah kondisi mental dimana seseorang mengalami serangan panik yang dipicu oleh trauma pengalaman masa lalu. Mengalami kejadian traumatis adalah hal yang berat bagi siapapun.Pelayanan kesehatan pada masyarakat sangat dibutuhkan untuk mendukung pola hidup masyarakat yang sehat. Keterbatasan pelayanan kesehatan pada masyarakat yang kurang memadai banyak mengalami dampak negatif terhadap beberapa masyarakat yang pengidap suatu penyakit terutama penyakit gangguan mental yang diakibatkan beberapa peristawa. Keterbatasan ini akan menjadi suatu kendala karena kurangnya infrastruktur kesehatan dalam hal konsultasi penyakit tersebut sehingga pengidap tidak mengetahui gejala gejala seperti apa yang telah dialami dan seberapa jauh penyakit sudah terindetifikasi, sehingga sangat dibutuhkan suatu solusi dan alternatif dalam menangani masalah keterbatasan pelayanan kesehatan.Dengan membangun suatu sistem yang dapat membantu para pengidap penyakit, diharapkan dapat memberikan solusi untuk para pengidap penyakit untuk melakukan suatu tindakan atau konsultasi terhadap seorang pakar berdasarkan sistem tersebut.
\end{abstract}

Kata Kunci: Post Trumatic Stress Disorder, Hybrid Case-Based Reasoning, Sistem pakar

\begin{abstract}
Post Traumatic Stress Disorder is a mental condition where a person experiences panic attacks that are triggered by past experience trauma. Having a traumatic event is a hard thing for anyone. Health services to the community are needed to support a healthy lifestyle. Limitations of health services in the community that are inadequate have a lot of negative impacts on some people who suffer from an illness, especially mental disorders caused by several events. This limitation will become an obstacle due to lack of health infrastructure in terms of consultation of the disease so that sufferers do not know the symptoms such as what they have experienced and how far the disease has been identified, so it is very much needed a solution and alternative in handling the problem of limited health services. By building a system that can help people with the disease, is expected to provide solutions for people with disease to take an action or consultation with an expert based on the system.
\end{abstract}

Keywords: Post Trumatic Stress Disorder, Hybrid Case-Based Reasoning, Expert Systems

\section{PENDAHULUAN}

Post Traumatic Stress Disorder adalah kondisi mental dimana seseorang mengalami serangan panik yang dipicu oleh trauma pengalaman masa lalu. Mengalami kejadian traumatis adalah hal yang berat bagi siapapun. Beberapa orang yang mengidap Post Traumatic Stress Disorder setelah mengalami peristiwa yang menyakitkan atau mengejutkan seperti, kecelakaan, pelecehan seksual, penindasan, kekerasan dalam rumah tangga, bencana alam dan insiden yang mengancam nyawa yang mengakibatkan para penderita gangguan mental mungkin selalu memikirkan kejadian traumatis ini dan dapat mempengaruhi pola hidup sehari-hari.

Pelayanan kesehatan pada masyarakat sangat dibutuhkan untuk mendukung pola hidup masyarakat yang sehat. Keterbatasan pelayanan kesehatan pada masyarakat yang kurang memadai banyak mengalami dampak negatif terhadap beberapa masyarakat yang pengidap suatu penyakit terutama penyakit gangguan mental yang diakibatkan beberapa peristawa. Keterbatasan ini akan menjadi suatu kendala karena kurangnya infrastruktur kesehatan dalam hal konsultasi penyakit tersebut sehingga pengidap tidak mengetahui gejala gejala seperti apa yang telah dialami dan seberapa jauh penyakit sudah terindetifikasi, sehingga sangat dibutuhkan suatu solusi dan alternatif dalam menangani masalah keterbatasan pelayanan kesehatan.

Dengan membangun suatu sistem yang dapat membantu para pengidap penyakit, diharapkan dapat memberikan solusi untuk para pengidap penyakit untuk melakukan suatu tindakan atau konsultasi terhadap seorang pakar berdasarkan sistem tersebut. Sistem tersebut dibangun berdasarkan peengetahuan layaknya seorang pakar sehingga disebut sistem pakar (Expert System). Sistem pakar yang dibangun akan membantu pegidap dalam proses pendiagnosaan guna mengetahui gejalagejala yang berkaitan dengan penyakit sehingga dapat di ketahui oleh pengidap, apa gejala dan solusi untuk setiap penyakit yang dierita oleh pengidap terutama penyakit Post Traumatic Stress Disorder. Untuk membangun sistem pakar yang diharapkan, dibutuhkan sebuah konsep untuk pengambilan keputusan yaitu sebuah metode Hybrid Case-Based Reasoning.

Metode Hybrid Case-Based Reasoning Merupakan metode untuk membangun suatu kecerdasan dimana prosesnya adalah untuk memberikan solusi berdasarkan solusi dari masalah lalu yang serupa. Hasil penelitian terdahulu menyatakan bahwa metode ini sangat cocok untuk diterapkan pada sebuah sistem pakar (expert system) untuk membantu dalam hal mendiagnosa penyakit gigi dan mulut yaitu "Implementasi sistem pakar diagnosa penyakit gigi dan mulut menggunakan metode Hybrid case-Based dan Rule-Based Reasoning"[1].

\section{METODE PENELITIAN}




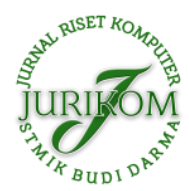

JURIKOM (Jurnal Riset Komputer), Vol. 7 No. 2, April 2020 e-ISSN 2715-7393 (Media Online), p-ISSN 2407-389X (Media Cetak) DOI 10.30865/jurikom.v7i2.2085 Hal 256-263

\subsection{Sistem Pakar}

Sistem pakar adalah salah satu cabang dari AI yang membuat penggunaan secara luas Knowladge yang khususnya untuk menyelesaikan masalah manusia tingkat pakar. Sistem pakar tediri dari dua utama yaitu : Basis Pengetahuan (Knowladge Base) dan motor inference (Inference Engine)[2].

\subsection{Metode Hybrid Case-Based Reasoning}

Cased Based Reasoning merupakan sebuah metode untuk memecahkan suatu permasalahan, metode ini memanfaatkan knowledgedari kasus-kasus yang sudah ada sebelumnya. Jika terdapat kasus baru yang belum ada pada kasus-kasus sebelumnya, maka metode ini akan melakukan learningdan menambahkannya pada knowledge base sebagai knowledgeyang baru sehingga knowledge yang dimiliki oleh sistem bertambah.Pada CBR, yang menjadi basis pengetahuan adalah faktafakta berupa kasus-kasus sebelumnya yang pernah ada dan serangkaian alur untuk memeriksa, menghitung, serta menyimpulkan suatu solusi dari permasalahan yang diberikan. Serangkain alur tersebuat antara lain: Retrieve, Retain, Reusedan Revise[4].

\subsection{Penyakit Post Traumatic Stress Disorder}

Post-Traumatic Stress Disorder atau gangguan stres pascatrauma adalah kondisi kejiwaan yang dipicu oleh kejadian tragis yang pernah dialami atau disaksikan. Contoh peristiwa traumatis yang dapat memicu kondisi ini adalah kecelakaan lalu lintas, bencana alam, tindak kejahatan seperti pemerkosaan atau perampokan, atau pengalaman di medan perang. PostTraumatic Stress Disorder termasuk kategori gangguan kecemasan yang membuat penderitanya tidak bisa melupakan atau sebaliknya tidak mau mengingat pengalaman traumatis tersebut, serta berpikir negatif terhadap diri sendiri dan dunia sekitarnya. Kondisi ini umumnya ditandai dengan mimpi buruk, merasa terisolir, kesal, memiliki perasaan bersalah, sulit berkonsentrasi, serta sulit tidur atau insomnia[9].

\section{HASIL DAN PEMBAHASAN}

Sistem pakar adalah sistem berbasis komputer yang menggunakan pengetahuan, fakta dan teknik penalaran dalam memecahkan masalah yang biasanya hanya dapat dipecahkan oleh seorang pakar hanya dalam bidang tertentu. berdasarkan hasil wawancara dengan tenaga medis di Rumah Sakit Jiwa Prof M Ildrem (dr. Elviana Barus, Sp.Kj) maka didapatkan suatu kesimpulan bagaimana cara mendiagnosa penyakit Post Traumatic Stress Disorder. Dalam membangun sebuah sistem pakar untuk mendiagnosa gejala Post Traumatic Stress Disorder, Sistem pakar ini menggunakan metode Hybrid Case-Based Reasoning untuk mengukur kemungkinan kepastiaannya.

Dengan demikian diperlukan pengetahuan yang akuisisi menjadi basis pengetahuan dengan mengetahui terlebih dahulu bagaimana mengenali suatu jenis penyakit yang diderita seseorang berdasarkan keluhan utama maupun gejala-gejala yang ditimbulkan serta sebab terjadinya penyakit. Untuk memenuhi syarat-syarat tersebut maka dibuat suatu struktur if_then yang dibaca dari database. Program ini diusahakan sesederhana mungkin agar mudah dimengerti pengguna.

Proses perhitungan presentase kepercayaan diawali dengan pemecahan sebuah rule yang memiliki premis majemuk, menjadi rule yang memiliki premis tunggal. Kemudian masing-masing aturan baru dihitung hybrid case based nya, sehingga diperoleh nilai hybrid case based untuk masing-masing aturan, Kemudian nilai tersebut dikombinasikan. Berikut ini gejala hasil kosultasi dari dr. Elviana Barus Sp.Kj Rumah Sakit Jiwa Prof. Dr. Muhammad Ildrem dengan masing-masing bobot pada tabel 1.

Tabel 1. Data Gejala Post Traumatic Stress Disorder

\begin{tabular}{cl}
\hline Kode Gejala & \multicolumn{1}{c}{ Nama Gejala } \\
\hline G01 & Berhalusinasi dan Mimpi Buruk \\
G02 & Takut Melihat Orang Ramai \\
G03 & Emosi Yang Sangat Tinggi \\
G04 & Mengalami Kecemasan yang berlebihan \\
G05 & Susah Tidur \\
G06 & Sesak Napas \\
G07 & Mual dan Diare \\
\hline
\end{tabular}

Tabel 2. Nilai Bobot

\begin{tabular}{ccc}
\hline No & Nilai Bobot & Keterangan \\
\hline 1 & 1 & Sangat yakin \\
2 & 0.8 & Yakin \\
3 & 0.6 & Cukup Yakin \\
4 & 0.4 & Kurang yakin \\
5 & 0.2 & Sedikit Yakin \\
6 & 0 & Tidak Tau \\
\hline
\end{tabular}


Dari hasil pembobotan nilai termologi diatas dapat ditentukan nilai tingkat presentasi kemungkinan positifnya penderita akan penyakit Post Traumatic Stress Disorder.

Tabel 3. Presentasi Kemungkinan

\begin{tabular}{ll}
\hline \multicolumn{1}{c}{ Tingkat Presentasi } & \multicolumn{1}{c}{ Nilai Kemungkinan } \\
\hline $0 \%-50 \%$ & Kemungkinan mengidap Penyakit \\
$51 \%-75 \%$ & Sedikit Kemungkinan Mengidap Penyakit \\
$76 \%-85$ & Kemungkinan Besar Mengidap Penyakit \\
$86 \%-100 \%$ & Positif teridap penyakit \\
\hline
\end{tabular}

Berdasarkan tabel Presentasi Kemungkinan diatas dapat ditentukan gejala penderita Post Traumatic Stress Disorder dengan berdasarkan data yang dimasukkan, maka dapat ditentukan proses pemilihan rule untuk penyakit, sebagai berikut:

Tabel 4. Rule Gejala-Gejala

\begin{tabular}{cc}
\hline Rule & \multicolumn{1}{c}{ Gejala } \\
\hline Rule 1 & IF G1, G2, G3, G4, G5, G6 THEN Diagnosa.... \\
Rule 2 & IF G1, G2, G3, G4, G5, G6 THEN Diagnosa... \\
Rule 3 & IF G1, G2, G3, G4, G5, G6 THEN Diagnosa... \\
Rule 4 & IF G1, G2, G3, G4, G5, G6 THEN Diagnosa.... \\
Rule 5 & IF G1, G2, G3, G4, G5, G6 THEN Diagnosa... \\
Rule 6 & IF G1, G2, G3, G4, G5, G6 THEN Diagnosa.... \\
\hline
\end{tabular}

Sesuai dengan konsep keputusan Hybrid Case based Reasoning yaitu untuk menemukan solusi berdasarkan masalah yang serupa pada masa masa yang lewat, dapat ditentukan data proses kedalam bentuk tabel sebagai berikut:

Tabel 5. Gejala Yang Dialami pasien/pengidap

\begin{tabular}{clccc}
\hline \multirow{2}{*}{ Kode } & \multicolumn{1}{c}{ Gejala } & \multicolumn{3}{c}{ Gangguan Pasien } \\
\cline { 3 - 5 } & & P1 & P2 & P3 \\
\hline G001 & Berhalusinasi dan Mimpi Buruk & - & - & - \\
G002 & Takut Melihat Orang Ramai & - & - & - \\
G003 & Emosi Yang Sangat Tinggi & - & - & - \\
G004 & Mengalami Kecemasan yang berlebihan & - & - & - \\
G005 & Susah Tidur & - & - & - \\
G006 & Sesak Napas & - & - & - \\
G007 & Mual dan Diare & - & - & - \\
\hline
\end{tabular}

Berikut ini langkah-langkah penyelesaian metode Hybrid Case Based Reasoning adalah sebagai berikut:

1. Menentukan gejala-gejala terjadinya penyakit Post Traumatic Stress Disorder pada seseorang.

2. Menyusun gejala-gejala tersebut kedalam sistem dengan pertanyaan yang di ajukan ke user.

3. Menghitung nilai tertinggi atau nilai kepercayaan yang didapat dari setiap gejala-gejala penyakit dengan metode hybrid Case Based.

Hasil akhir berupa persentase yang dijadikan sebagai nilai kepercayaan dari setiap pertanyaan yang dijawab oleh user, dan kemudian hasil itu menentukan bahwa orang tersebut menderita penyakit Post Traumatic Stress Disorder. Nilai 0 menunjukan bahwa user tidak mengalami gejala seperti yang dinyatakan oleh sistem. Semakin pengguna konsultasi yakin bahwa gejala tersebut memang dialami, maka semakin tinggi pula hasil presentase keyakinan yang diperoleh.

$$
(\mathrm{A} . \mathrm{B})=\frac{A . B}{|A \cdot| \cdot|B|}=\frac{\sum_{i}^{n}=1(A i \cdot B i)}{\sqrt{\sum_{i}^{n}=A_{i}^{n} \cdot \sum_{i}^{n}=B_{i}^{n}}}
$$

Tabel 6. Gejala Yang Dimiliki Pengidap

\begin{tabular}{clcc}
\hline Kode Gejala & \multicolumn{1}{c}{ Nama Gejala } & Keterangan & BOBOT \\
\hline G001 & Berhalusinasi dan Mimpi Buruk & Sangat Yakin & 1 \\
G002 & Takut Melihat Orang Ramai & Cukup Yakin & 0.6 \\
G003 & Emosi Yang Sangat Tinggi & Yakin & 0.8 \\
G004 & Mengalami Kecemasan yang berlebihan & Sangat Yakin & 1 \\
G005 & Susah Tidur & Tidak yakin & 0.2 \\
G006 & Sesak Napas & Tidak tau & 0 \\
G007 & Mual dan Diare & Yakin & 0.8 \\
\hline
\end{tabular}

Berdasarkan dari tabel gejala diatas dapat dilakukan pendiagnosaan dengan mencocokan gejala yang akan dilakukan sistem terkait gejala yang diidap oleh penderita Post Traumatic Strees Disorder. Seperti tabel dibawah ini: 
Tabel 7. Gangguan Yang Dialami Pengidap

\begin{tabular}{clcc}
\hline \multirow{2}{*}{ Kode } & \multicolumn{1}{c}{ Gejala } & \multicolumn{2}{c}{ Gangguan Pasien } \\
\cline { 3 - 4 } & & P1 & P2 \\
\hline G001 & Berhalusinasi dan Mimpi Buruk & 1 & 1 \\
G002 & Takut Melihat Orang Ramai & 0.8 & 1 \\
G003 & Emosi Yang Sangat Tinggi & 0.6 & 0.8 \\
G004 & Mengalami Kecemasan yang berlebihan & 1 & 0.6 \\
G005 & Susah Tidur & 0.2 & 0 \\
G006 & Sesak Napas & 0.8 & 0.6 \\
G007 & Mual dan Diare & 1 & 1 \\
\hline
\end{tabular}

Setelah gangguan yang dialami pengidap ditentukan, selanjutnya tentukan nilai dari maing masing kepastian berdasarkan rule.

Jika User $=$ A Maka

Pengidap $=\mathrm{B}$

$\mathrm{A}=1|0.6| 0.8|1| 0.2|0| 1 \mid$

$\mathrm{B}=\mathrm{P} 1=1|0.8| 0.6|1| 0.2|0.8| 1$

$\mathrm{B}=\mathrm{P} 2=1|1| 0.8|0.6| 0|0.6| 1$

Setelah bobot gejala pengidap ditentukan maka lakukan perhitungan seperti tahapan dibawah ini.

Tahap pertama :

$\sum_{I}^{n} 1[A i . B i]=(1 \times 1)+(0.6 \times 0.8)+(0.8 \times 0.6)+(1 \times 1)+(0.2 \times 0.2)+(0 \times 0.8)+(0.8 \times 1)=3.8$

$\sqrt{\sum_{i}^{n}=A_{i}^{n} \cdot \sum_{i}^{n}=1 B_{i}^{n}=\{1+0.36+0.64+1+0.4+0+0.64\} *\{1+0.8+0.6+1+0.2+0.8+1\}}$

$$
=4.04 * 4.4=21.816
$$

$\frac{\sum_{i}^{n}=1(\mathrm{Ai} . \mathrm{Bi})}{\sqrt{\sum_{i}^{n}=A_{i}^{n}} \cdot \sum_{i}^{n}=1 B_{i}^{n}}=\frac{3.8}{\sqrt{21.816}}=\frac{3.8}{4.6}=0.83=83 \%$

Tahap Kedua :

$\sum_{I}^{n}=1[A i * B i]==(1 \times 1)+(0.6 \times 1)+(0.8 \times 0.8)+(1 \times 0.6)+(0.2 \times 0)+(0 \times 0.6)+(1 \times 1)=3.84$

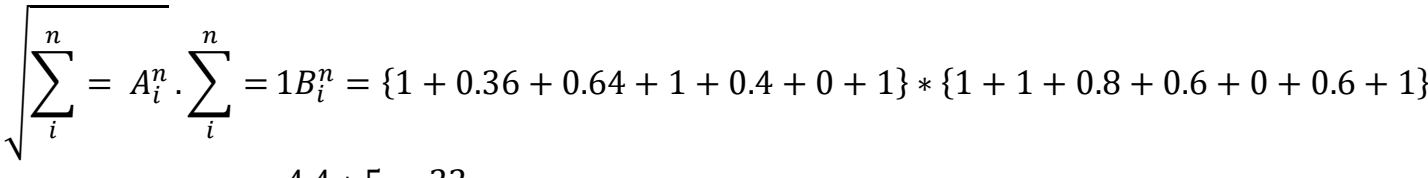

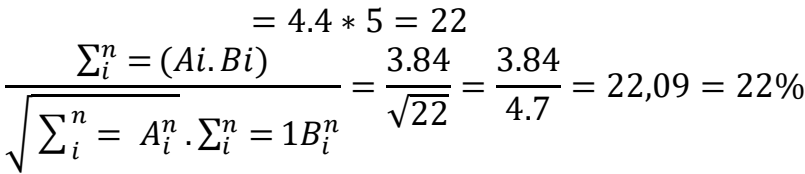

Setelah dilakukan tahap tahap diatas maka dapat disimpulkan bahwa nilai kepastian paling banyak akan menjadi hasil diagnosa pada pengidap penyakit Post Traumatic Stress Disorder, Sehingga dapat disimpulkan bahwa:

Tabel 8. Hasil perhitungan Pengidap

\begin{tabular}{llrcl}
\hline NO & PENGIDAP & STATUS & SIMILIRITAS & \multicolumn{1}{c}{ KETERANGAN } \\
\hline 1 & P1 & TERDIAGNOSA & $83 \%$ & $\begin{array}{l}\text { Kemungkinan Besar } \\
\text { Mengidap Penyakit } \\
2\end{array}$ \\
& P1 & TERDIAGNOSA & $22 \%$ & $\begin{array}{l}\text { Kemungkinan mengidap } \\
\text { Penyakit }\end{array}$ \\
\hline
\end{tabular}

\subsection{Implementasi}

Tampilan data gejala penyakit dapat dilakukan dengan cara memilih menu "Data Gejala" pada menu utama. Menu ini sebagai menu informasi tentang gejala Penyakit Post Traumatic disorder yang telah diketahui sampai saat ini. Tampilan menu Penyakit Post Traumatic disorder dapat dilihat pada gambar seperti dibawah ini : 


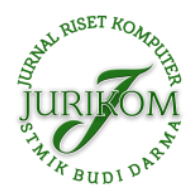

JURIKOM (Jurnal Riset Komputer), Vol. 7 No. 2, April 2020 e-ISSN 2715-7393 (Media Online), p-ISSN 2407-389X (Media Cetak) DOI 10.30865/jurikom.v7i2.2085 Hal 256-263

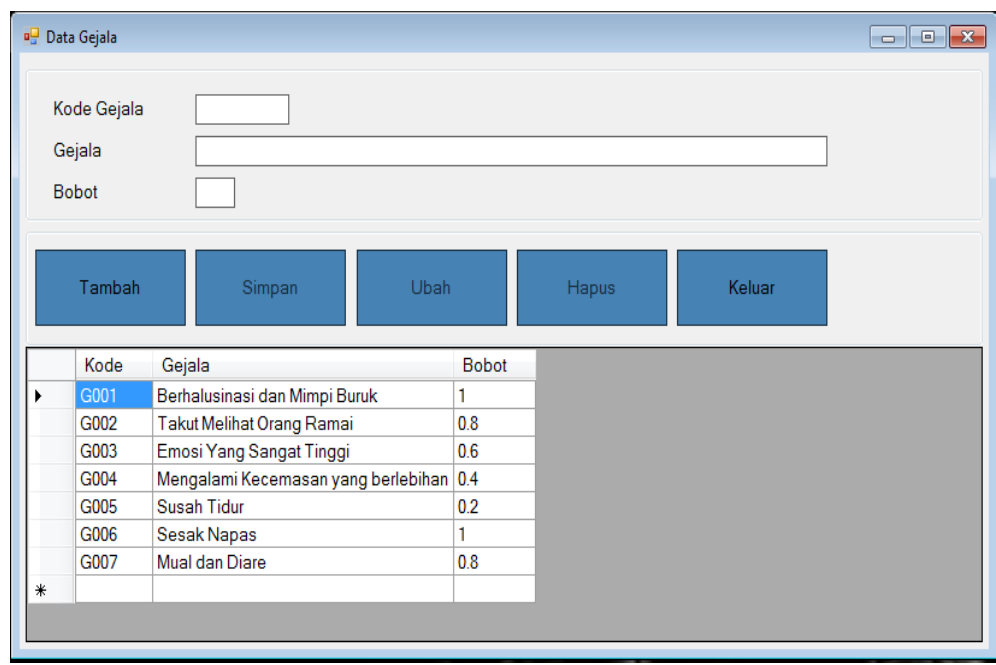

Gambar 1. Data Gejala

Tampilan Data Kasus Penyakit Post Traumatic Stress Disorder dapat dilakukan dengan cara memilih menu "Data Kasus" pada menu utama. Menu ini sebagai menu informasi tentang Data Kasus yang telah diketahui sampai saat ini. Tampilan menu Data Kasus dapat dilihat pada Gambar 2. seperti dibawah ini :

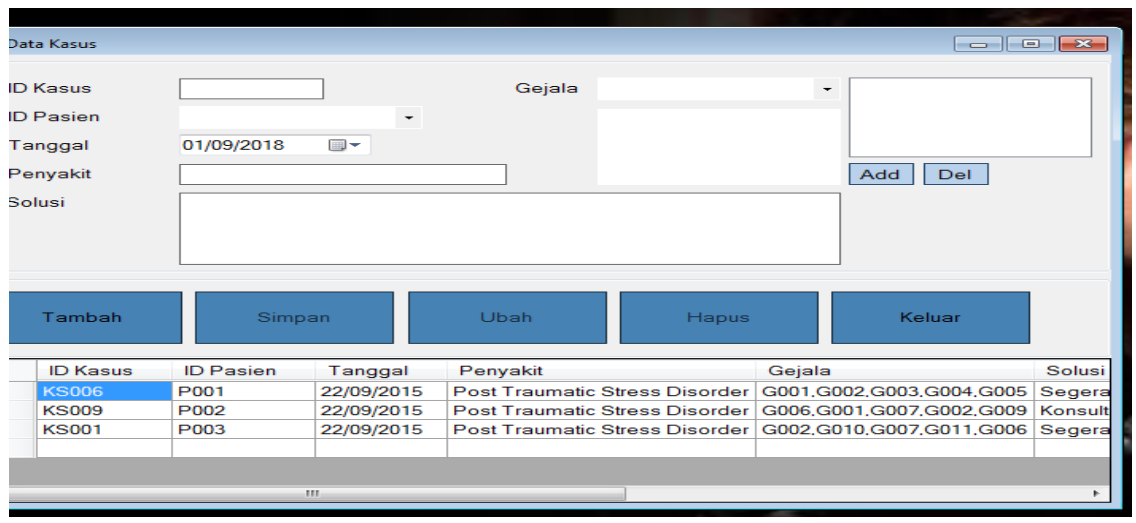

Gambar 2. Tampilan Data kasus Post Traumatic Stress Disorder

Tampilan Pengidap dapat dilakukan dengan cara memilih menu "Diagnosa dan Memilih data Pengidap" pada Post Traumatic Stress Disorder. Tampilan menu Data pengidap dapat dilihat pada Gambar 3 seperti dibawah ini :

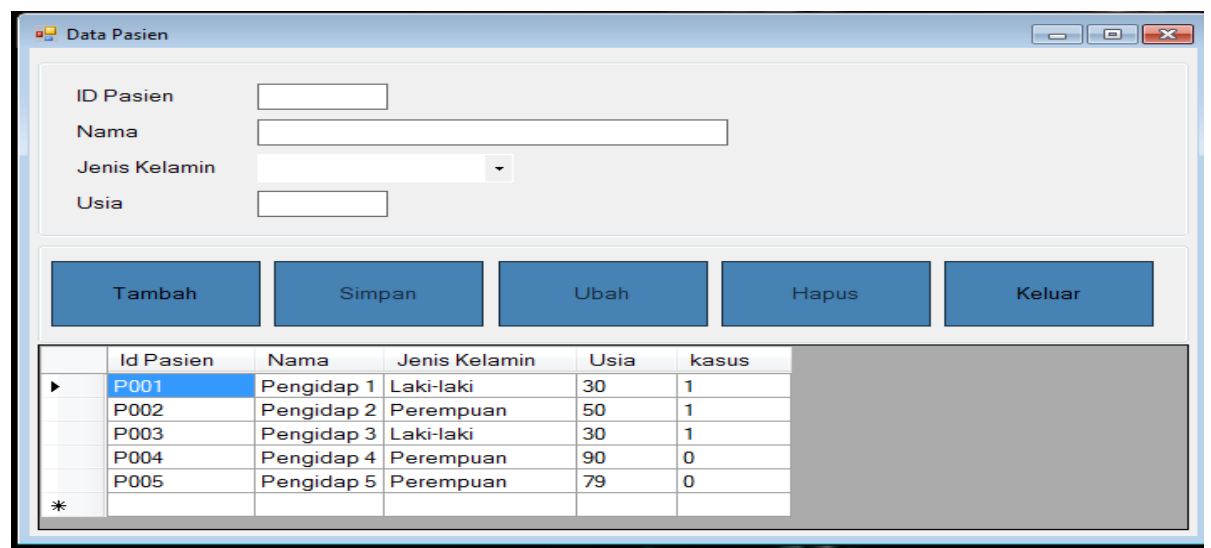

Gambar 3. Tampilan Menu Data Pengidap

Tampilan Input Data Pengidap Diagnosa dapat dilakukan dengan cara memilih menu "Diagnosa” pada menu utama. Menu ini berfungsi sebagai halaman untuk mengisi data pengidap oleh user. Tampilan menu data pengidap diagnosa penyakit dapat dilihat pada Gambar 4. seperti dibawah ini : 


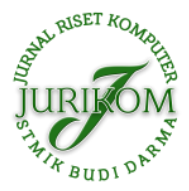

JURIKOM (Jurnal Riset Komputer), Vol. 7 No. 2, April 2020 e-ISSN 2715-7393 (Media Online), p-ISSN 2407-389X (Media Cetak) DOI 10.30865/jurikom.v7i2.2085

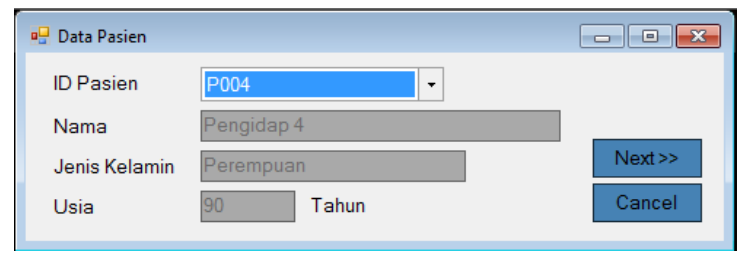

Gambar 4. Tampilan Menu input Diagnosa

Tampilan Proses Diagnosa dapat dilakukan dengan cara memilih menu "Diagnosa" pada menu utama. Pada menu ini berfungsi sebagai proses diagnosa setelah kita menginputkan data pengidap selanjutnya akan mengarahkan kita ke proses diagnosa setelah kita memilih gejala gejala penyakit. Tampilan Proses Diagnosa dapat dilihat pada Gambar 5. seperti dibawah ini :

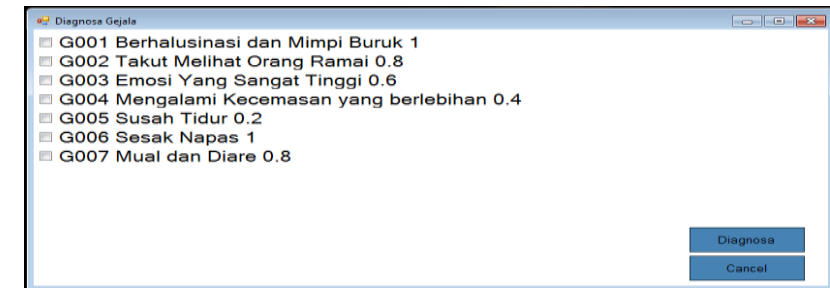

Gambar 5. Tampilan Proses Diagnosa

Tampilan Hasil Diagnosa dapat dilakukan dengan cara memilih menu "Diagnosa dan memilih pengidap dan memasukkan data gejala sehingga terjadi proses diagnosa" pada menu utama. Menu ini berfungsi untuk menampilkan hasil diagnosa penyakit. Tampilan Hasil Diagnosa dapat dilihat pada Gambar 6. seperti dibawah ini :

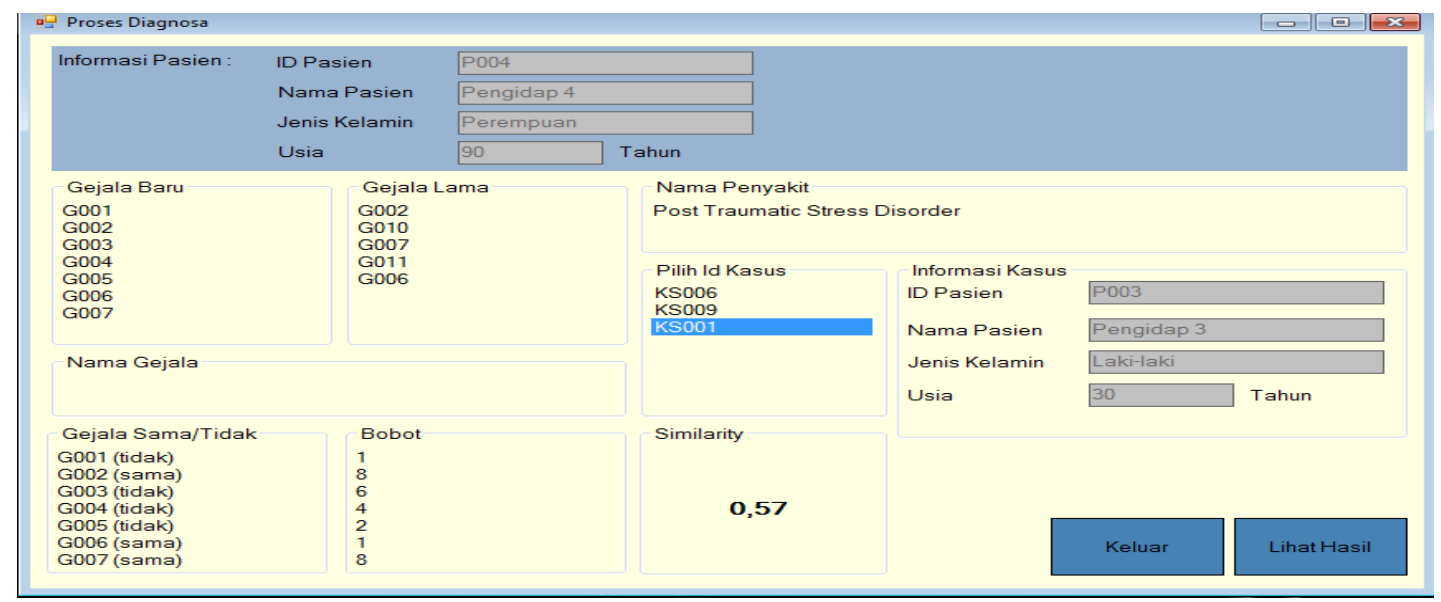

Gambar 6. Hasil Diagnosa

Tampilan Laporan Diagnosa dapat dilakukan setelah kita selessai mendiagnosa berdasarkan gejala yang kita inputkan pada menu diagnosa. Menu ini menampilan hasil diagnosa dan solusi diagnosa. Tampilan ini dapat kita lihat pada gambar 7 seperti dibawah ini.

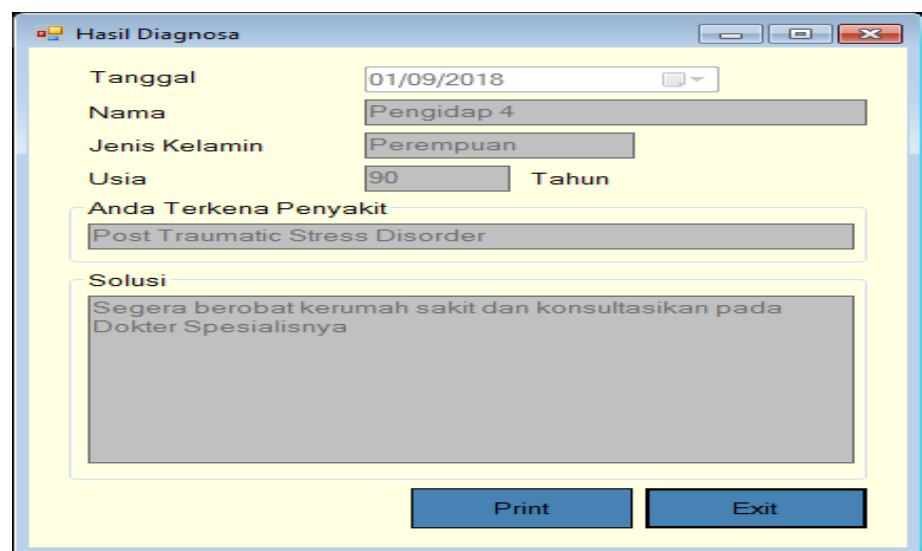

Gambar 7. Laporan dan Solusi diagnosa 


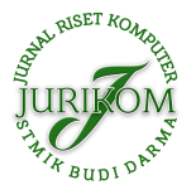

JURIKOM (Jurnal Riset Komputer), Vol. 7 No. 2, April 2020 e-ISSN 2715-7393 (Media Online), p-ISSN 2407-389X (Media Cetak) DOI 10.30865/jurikom.v7i2.2085

Tampilan Input Diagnosa kedua merupakan tampilan proses diagnosa pada pengidap kedua. Tampilan ini dilakukan dengan cara memilih menu dan diagnosa. Tampilan ini dapat dilihat seperti gambar dibawah ini.

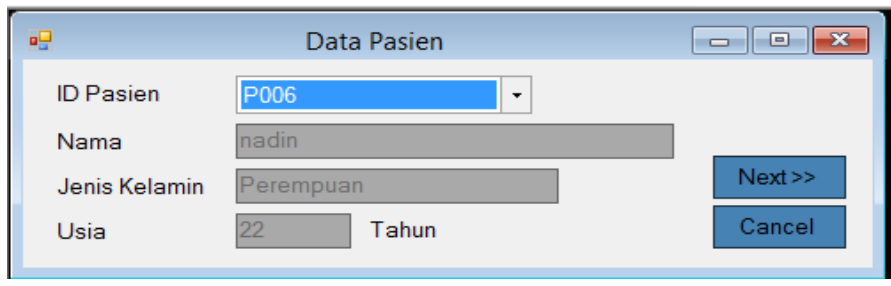

Gambar 8. Tampilan Input Pengidap Kedua

Tampilan ini adalah tampilan dimana pengidap memilih dan memasukkan data gejala yang dialami oleh pengidap. Tampilan ini dapat dilihat seperti gambar dibawah ini.

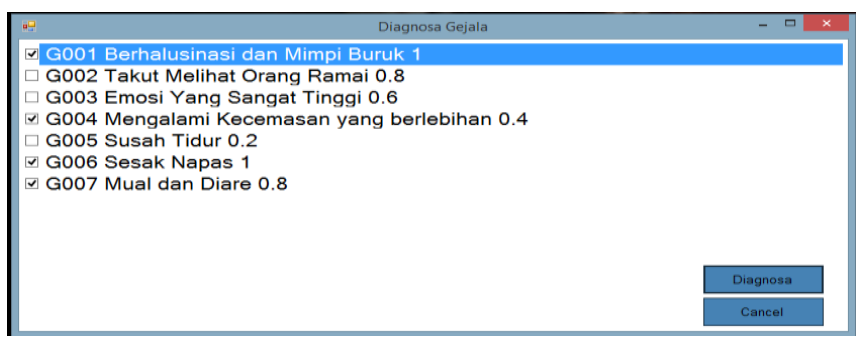

Gambar 9. Tampilan Proses Diagnosa pengidap kedua

Tampilan hasil Diagnosa pengidap Kedua. Merupakan tampilan dari hasil diagnosa pengidap kedua tampilan ini dapat dilihat seperti gambar dibawah ini.

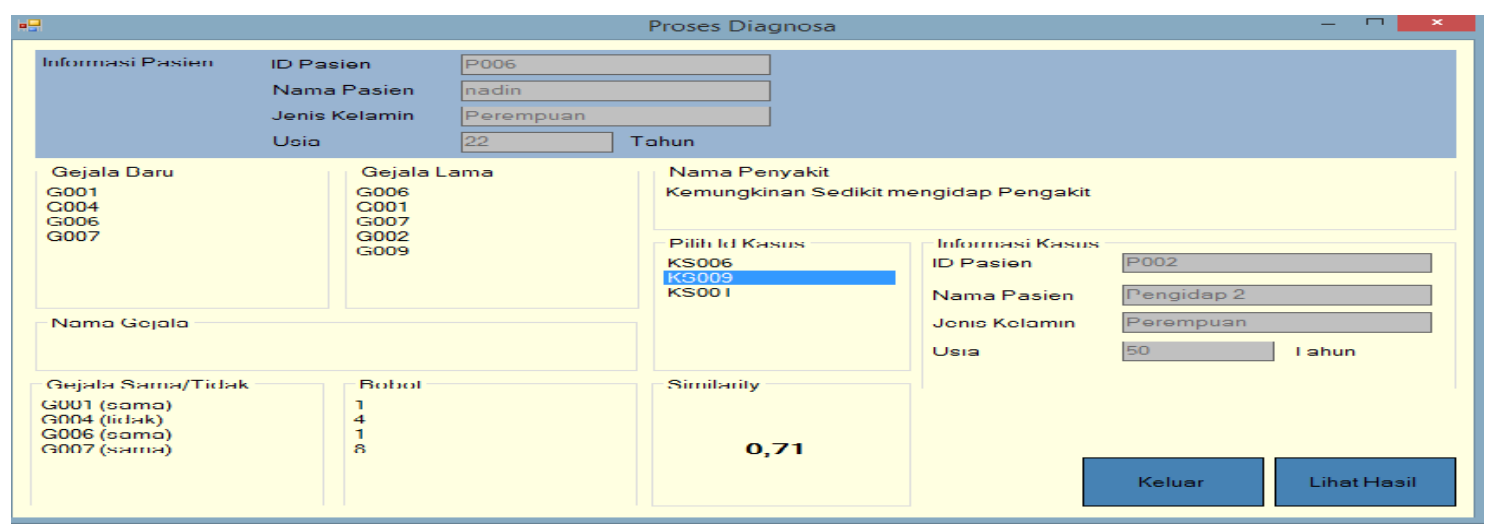

Gambar 10. hasil Diagnosa Pengidap kedua

Tampilan Laporan Dan Solusi dari pengidap kedua adalah menampilkan hasil diagnosa yang dialami pengidap kedua berdasarkan gejala yang dialami. Tampilan ini dapat diihat seperti gambar dibawah ini.

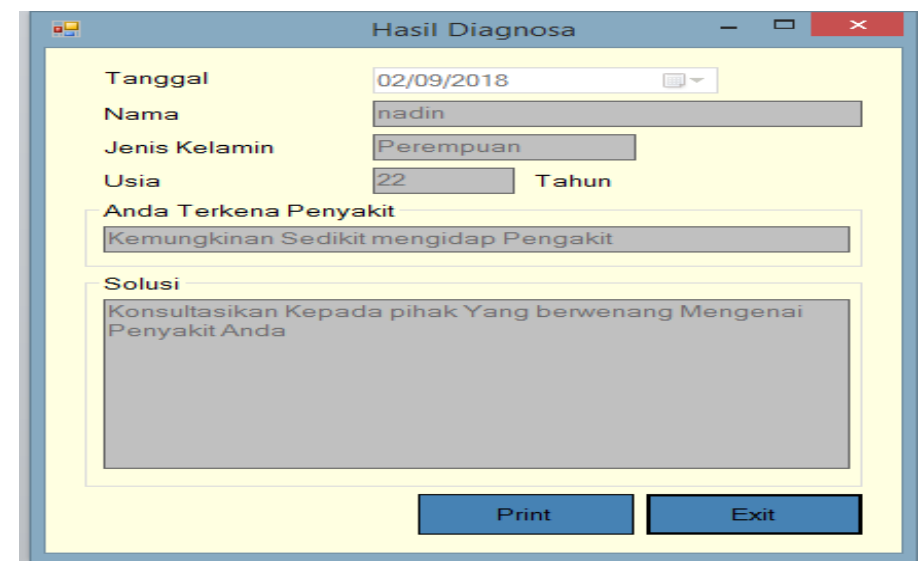

Gambar 11. Laporan Hasil diagnosa Pengidap Kedua 


\section{KESIMPULAN}

Berdasarkan dari hasil penelitian yang telah dibahas pada skripsi ini dapat diperoleh kesimpukan sebagai berikut :

1. Sistem pakar dapat mendiagnosa seseorang yang mengalami gejala-gejala penyakit Post traumatic Stress Disorder

2. Penggunaan metode Hybrid case based reasoning untuk mendiagnosa penyakit Post traumatic Stress Disorder dapat dilakukan dengan rumus atau perhitungan yang telah ditetapkan pada metode Hybrid case based reasoning

3. Untuk mendiagnosa penyakit Post traumatic Stress Disorder dapat dilakukan dengan alat bantu berupa aplikasi yang telah dirancang menggunakan bahasa pemrograman Visual basic 2008

\section{REFERENCES}

[1] Ade Romadhani, Siti Saadah M.Abuduracchmand Irfandi, "Implementasi sistem pakar diagnosa penyakit gigi dan mulut menggunakan metode Hybrid case-Based dan Rule-Based Reasoning," Indonesia Symposium On Computing, pp. 219-225, 2015

[2] Muhammad Arhami, Konsep Dasar Sistem Pakar, 1st ed., ANDI, Ed. Yogyakarta, Indonesia: ANDI OFFSET, 2005.

[3] Anita Desaini, Konsep Kecerdasan Buatan, 1st ed., Dwiberta hardjono, Ed. Yogyakarta, Indonesia: C.V ANDI OFFSET, 2006.

[4] Danang Junaedi, S.T., M.T., Drs. Mahmud Imrona, M.T. Arman Dwi Jatmiko, "ANALISIS DAN IMPLEMENTASI SISTEM PAKAR DENGAN METODE CASE BASED REASONING DAN RULE BASED REASONING (STUDI KASUS: DIAGNOSIS PENYAKIT DEMAM BERDARAH)," e-Proceeding of Engineering, vol. 4, no. 2, pp. 3269-3276, Agustus 2017.

[5] Rosa A.S, Rekayasa Perangkat Lunak, I ed., Informatika Bandung, Ed. Bandung, Indonesia: Informatika Bandung, 2016.

[6] Pembuatan Sistem Informasi Penjualan Pada Ade Jaya Ponsel Dengan Menggunakan Visual Basic," Jurnal Ilmiah DASI , vol. 12, no. 4, pp. 39-44, Desember 2013.

[7] FATHANSYAH, BASIS DATA, Revisi ed., Informatika Bandung, Ed. Bandung, Indonesia: Penerbit Informatika, 2012.

[8] Sistem Informasi Perpustakaan Berbasis Ms Access pada Jurusan Administrasi Niaga Politeknik Negeri Ujung Pandang," Jurnal Sainsmat, vol. IV, no. 2, pp. 175-195, September 2015. 